\title{
A Study of College- Enterprise Cooperative Major Teaching Model and SPSS Teaching Effect Analysis
}

\author{
Jun Liu, Xiao-QiuYao \\ Donghai Science and Technology College of Zhejiang Ocean University, Zhoushan, China \\ E-mail: 1992579403@qq.com, 24461781@qq.com
}

\begin{abstract}
It is a major issue for independent colleges to foster eligible applied technique-oriented professionals accepted by the society. The paper studies the cooperation of college and enterprises in computer science and technology major and its effect. By exploring the teaching planning, course setting and teaching practice, it put forwards a set of feasible teaching model.
\end{abstract}

Keywords-Independent College; college-enterprise cooperation; curriculum system; teaching model

\section{INTRODUCTION}

In a speech made by $\mathrm{Lu} \mathrm{Xin,} \mathrm{the} \mathrm{vice} \mathrm{minister} \mathrm{of}$ Education Ministry, in China Development Summit Forum in March, 2014, he urged that over 600 regional colleges should transform themselves into applied technique-oriented or vocation education-oriented ones ${ }^{[1]}$, which happens to represent the training goals of independent colleges. Over a long period of time, colleges in China overemphasized the implantation and accumulation of knowledge as well as the systematicness and integrity of subject knowledge while neglecting the training of students' abilities ${ }^{[2]}$. Times calls for colleges to bear partial social functions such as technology development, technology transfer and technical service and to plunge into economy building by integrating themselves with education, scientific research, production and service under an effective mechanism so that they can expand their advantages of self-development, strengthen their competitiveness and accelerate their paces in training applied professionals ${ }^{[3-4]}$. College-enterprise cooperation is a new pattern. In a broad sense, it is a mode for educational institutions and enterprises to cooperative with each other in students training, scientific research and technical service ${ }^{[5]}$. Enterprises represent the main body demanding the applied engineering professionals. As they know best their development and their industries, they have the clearest objectives for professionals they need.

\section{COLLEGE-ENTERPRISE COOPERATIVE TRAINING MODEL}

The training model of computer science and technology major under the cooperation of our college and enterprises can be simplified as $2+1+1$. Teachers conduct their teaching in the first two years and part of the basic courses of the major will be taught so as to enable the students to have enough time to undertake targeted major-oriented learning. In the third year, some advanced trainers from enterprises will conduct the teaching with the assistance of the teachers from our colleges. Major-oriented courses will be taught and practical training will be implemented under the guide of introduced projects. Trainers for enterprises will adjust teaching and training contents and combine digital teaching system with classroom teaching to meet the demands of society. In the fourth year, students will undertake the practical training in enterprises. Enterprises will work out a three-month job simulation for students. Divided into several teams, students are required to complete a practical project offered by enterprises in a set mode. The training project will be used as students' graduation project and students will accomplish it in the three months. College teachers will guide them to finish graduation thesis or project report. The college-enterprise cooperation in students' graduation project establishes a new teaching environment which breaks the traditional model. It makes up the lack of practicability of traditional graduation projects and proves effective in improving students' innovativeness, awareness of innovation and comprehensive abilities. In the second half of fourth year, students will work as interns in different posts offered by enterprises. Most of them will become a member of the staff and get themselves employed.

\section{CURRICULUM CONSTRUCTION}

The principle by which the college-enterprise major curriculum is built can be summarized as "highlighting skills training while imparting adequate theoretic knowledge". The content of the curriculum can be characterized as "little, new, refined". The curriculum is implemented in modules, which means courses with similar features or functions are set in a course unit module. Therefore, students can build their own curriculum according to their individual needs. With the flexible curriculum, nuclear module and major-oriented module can be constructed upon the basic courses. The curriculum includes general education courses, basic courses and major-oriented core courses. Original optional courses can be replaced by courses conducted by enterprise, project training, curriculum design and comprehensive design.

\section{A. Constructing Modular Curriculum Platform and Establishing Feasible Theoretical Knowledge System}

Curriculum platform includes all the basic courses, consisting of fundamental courses platform, basic courses platform, major-oriented core courses platform and enterprise's training platform. The first three platforms are constructed by college teachers. Major-oriented core courses includes network programming, microcomputer principle, database principle, operation system, computer network security and software engineering, based on which follow-up 
enterprise core courses are conducted. Enterprise core courses highlight students' ability to develop software of computer science. Aiming at engineering practice, a comprehensive curriculum system is built with database developing technology, Java programming, web developing, project developing and project training as its nuclear core. In this platform, professional trainers and technical staffs from Daren Science and Technology Group are responsible for the textbooks, courseware creation and other teaching activities. It lays stress on students' practical ability.

B. Optimizing Practice Platform and Propelling the Practice Teaching Reform of Computer Science Technology Major

Firstly, we will take advantage of the resource in the lab and rid all the drawbacks of traditional lab courses.

Assignments are given to students in advance and students are divided into groups in lab courses. At the beginning of the lab course, students are required to validate basic knowledge. In the middle period, students are asked to design the task. In the final part, students will conduct a comprehensive design. Students will solve all the problems by themselves and no solution is given to the assignment, the requirement of which is conceptual. In this way, students' subject initiative will be given full play.

Secondly, enterprise will build a training base in college and develop a complete training platform. In the third year, enterprise will motivate students to accomplish projects and offer major-oriented courses so as to improve their engineering qualities. From the summer vocation in the third year, students will spend three months in the training base. Enterprises will assign workable tasks to students. With their enthusiasm and imitativeness stimulated and their comprehensive abilities strengthened, students will achieve a true understanding and mastery of all courses and fill in the post offered by the enterprise.

\section{SPSS TEACHING EFFECT ANALYSIS OF COLLEGE-ENTERPRISE MAJOR}

A questionnaire survey was conducted for graduates in 2015 and seniors in college, the purpose of which is to check the effect of the college-enterprise cooperative teaching. College-enterprise Cooperative Teaching Effect Questionnaire for Computer Major Students is designed by the author and group test method is adopted

Statistical Result and its Analysis

Statistical Result and its Analysis

\section{A. An Overall Information}

TABLE I. SEX BACKGROUND

\begin{tabular}{lccc}
\hline Sample & frequency & percent & $\begin{array}{c}\text { Valid percent } \\
\text { cumulative percent }\end{array}$ \\
\hline Male & 67 & 81.7 & 82.7 \\
\hline Female & 14 & 17.1 & 17.3 \\
\hline Valid Total & 81 & 98.8 & 100.0 \\
\hline Deficiency & 1 & 1.2 & \\
\hline total & 82 & 100 & \\
\hline
\end{tabular}

TABLE II.CLASSES OF THE MAJOR

\begin{tabular}{lccc}
\hline Sample & frequency & percent & Valid percent \\
\hline Grade 11 computer & 40 & 48.8 & 53.3 \\
Grade 11 information & 18 & 22 & 24 \\
Grade 10 computter & 17 & 20.8 & 22.6 \\
Deficiency & 7 & 8.4 & \\
Total & 82 & 100.0 & 100.0 \\
\hline
\end{tabular}

TABLE III.

DESCRIPTIVE STATISTICS

\begin{tabular}{|c|c|c|c|c|c|}
\hline & $\mathbf{N}$ & Minimum value & Maximum value & Average value & $\begin{array}{l}\text { Standard } \\
\text { deviation }\end{array}$ \\
\hline $\begin{array}{l}\text { motivated by the teaching plans of the } \\
\text { major to pursue study }\end{array}$ & 82 & .00 & 100.00 & 13.4146 & 34.29068 \\
\hline $\begin{array}{l}\text { Motivated by teachers of the major to } \\
\text { pursue study }\end{array}$ & 82 & .00 & 100.00 & 10.9756 & 28.71499 \\
\hline $\begin{array}{l}\text { Expecting to improve learning } \\
\text { atmosphere }\end{array}$ & 82 & .00 & 100.00 & 10.5691 & 29.10557 \\
\hline $\begin{array}{l}\text { Enriching myself by reserving } \\
\text { knowledge }\end{array}$ & 82 & .00 & 100.00 & 13.0081 & 33.43856 \\
\hline $\begin{array}{l}\text { Unwilling to accept the job offered by } \\
\text { Daren in Hangzhou }\end{array}$ & 82 & .00 & 100.00 & 6.5041 & 23.09343 \\
\hline $\begin{array}{l}\text { Better than idling away in dorms an } \\
\text { playing computer games }\end{array}$ & 82 & .00 & 100.00 & 14.2276 & 31.44027 \\
\hline $\begin{array}{l}\text { To meet the demands of professional } \\
\text { training }\end{array}$ & 82 & .00 & 100.00 & 2.8455 & 14.99997 \\
\hline other & 82 & .00 & 100.00 & 6.0976 & 22.90797 \\
\hline valid N（status） & 82 & & & & \\
\hline
\end{tabular}


B. Quality analysis of the questionnaire

TABLE IV. A SUMMARY OF PROCESSED CASES

\begin{tabular}{cc|c|c}
\hline \hline & & $\mathrm{N}$ & $\%$ \\
\hline \multirow{4}{*}{ cases } & valid & 54 & 65.9 \\
& excluded & 28 & 34.1 \\
& Total & 82 & 100.0 \\
\hline
\end{tabular}

Table IV demonstrates that valid questionnaire information is obtained from 54 copies, accounting for $65.9 \%$ of the total. In following table, the overall reliability of questionnaire is 0.902, which indicates that questionnaire scale and its structural design is excellent and data information from it is reliable.

TABLE V

AN ANALYSIS OF QUESTIONNAIRE VALIDITY AND RELIABILITY

\begin{tabular}{|c|c|c|c|c|c|c|}
\hline \multirow{2}{*}{ 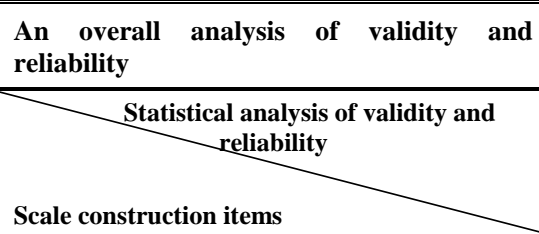 } & \multicolumn{3}{|c|}{$\begin{array}{l}\text { Scale construction reliability } \\
\text { Reliability Statistics }\end{array}$} & \multicolumn{3}{|c|}{$\begin{array}{l}\text { Scale construction validity } \\
\text { KMO and Bartlett's Test }\end{array}$} \\
\hline & $\begin{array}{l}\text { questionnaire } \\
\text { Cronbach's } \alpha\end{array}$ & $\begin{array}{l}\text { Reliability } \\
\text { based on } \\
\text { standard } \\
\text { itemsa }\end{array}$ & $\begin{array}{l}\text { N of } \\
\text { Items }\end{array}$ & $\begin{array}{l}\text { KMO } \\
\text { value }\end{array}$ & $\begin{array}{l}\text { Bartlett's Test } \\
\text { of Sphericity }\end{array}$ & Sig \\
\hline Questionnaire as a whole & 0.902 & 0.906 & 33 & 0.549 & 1422.106 & 0.000 \\
\hline $\begin{array}{c}\text { 1. Frequency of engagement in teaching } \\
\text { activities }\end{array}$ & 0.752 & 0.718 & 10 & 0.727 & 328.423 & 0.000 \\
\hline 2. Faculty of enterprise & 0.676 & 0.718 & 5 & 0.717 & 104.241 & 0.000 \\
\hline 5. Stimulation by studying in enterprise & 0.920 & 0.921 & 11 & 0.863 & 545.781 & 0.000 \\
\hline $\begin{array}{l}\text { 6.self-perception after receiving cooperative } \\
\text { training }\end{array}$ & 0.895 & 0.896 & 5 & 0.817 & 236.195 & 0.000 \\
\hline
\end{tabular}

\section{Result Analysis}

An SPSS analysis of the questionnaire reveals that there are both advantages and disadvantages of college-enterprise cooperative running for undergraduate students to pursue study. As for advantages, students have clearer learning objectives, more definite requirements for themselves and better readiness for future career. The disadvantages come from the adverse problems in the questionnaire. As students have stated in discussion meeting, their expectations to pursue knowledge in college are not fulfilled and they feel a sense of loss, which also represents the advantages of graduate education compared with vocational education and profession training. In other words, we need to rid the drawbacks of training model of graduate education within the college, make up the imperfect aspects and improve talent training mode of computer science and technology major.

\section{CONCLUSION}

College-enterprise major training proves to be an effective mode to train applied technique-oriented students. However, it deserves our further study and exploration to have undergraduate students master professional ability, foster their follow-up study ability and cultivate their humane qualities.

\section{REFERENCES}

[1] Zhou Hui, Shen Junhan, "A Heated Debate Triggered by the Transformation over 600 Regional Colleges into Applied Technique-oriented or Vocation Education-oriented ones". 21th Century Economic Report, 3rd ed., pp. 11-13, Apr. 2014.

[2] Kong Xiameng, "A Study of Career Education Courses in College", Reserved place: Southeast University, pp. 109-113, 2013.

[3] Zhang Dongpin, Pan Xiaojun, Geng Yu, "Practice and Study of the College-enterprise Cooperative Production and Research Operation Mechanism and Management Mode", China Power Education, vol.23, pp. 78-80, 2009(23).

[4] Shao Hongyan, Zheng Chunlong, "A Tentative Exploration of College-enterprise cooperative Laboratory Building mode and Operation Mechanism", Experiment Research and Exploration, vol.26, no.7, pp23-26, 2007.

[5] Liu Xingli, Hong Liang, Guan Fengyan, "A Digital Learning Supportive Service Model of College-enterprise Cooperative Talent-training", Heilongjiang High Education Research, vol.9, pp90-93, 2013 